\title{
ANALISIS PERISTIWA PENYEBAB PADA KETERLAMBATAN PROYEK APARTEMEN
}

\author{
Moch Afif Rosdianto, Mokh Suef, Endah Angreni \\ Magister Manajemen Teknologi, Institut Teknologi Sepuluh November Surabaya \\ e-mail: afifrosdianto@gmail.com
}

\begin{abstract}
A Project could be told success if it had a capability to fulfill a project's goal, which was project could be done either in time or do not have a major lateness. Many things were affecting project buildings processing. This research purpose was to analyze whose causing lateness for apartment buildings project event in Surabaya. To analyze so many cause lateness event would be needed a systematic method approach. This research's method was used a Fault Tree Analysis (FTA) Method which was used to seek cause event and the probability of lateness. Not only two of those methods, but also expert judgment technique was conducted by using questionnaire to seek probability and to analyze variable cause event. As a result of FTA method was obtained a very high probability of lateness with the main cause event was classified into 4 groups, were caused by owner, caused by supervising consultants, caused by contractor, and caused by environment circumstances. From four of those main causes was obtained some results, first of all from owner's perspective were a lot of assignment alteration and late payment installment to contractor, second of all from supervising consultants' perspective was a checklist survey result in certain area, the contractor's work could not be continued because of such a certain things, third of all from contractor's perspective was caused by inaccurate work method, and the last of all from environment circumstances was the local people felt so agitated because of the project location to close to them.
\end{abstract}

Keywords: cause lateness event, fault tree analysis, probability

\section{PENDAHULUAN}

Keterlambatan dalam menyelesaikan suatu proyek dapat menghambat bahkan dapat menyebabkan terhentinya kegiatan proyek tersebut. Untuk itu, sebelum melaksanakan proyek konstruksi perlu perencanaan yang matang agar proyek tersebut dapat berjalan dengan lancar. Keterlambatan konstruksi dapat didefinisikan sebagai penyelesaian pembangunan dalam memenuhi target waktu pengerjaan melebihi tanggal yang telah disepakati oleh seluruh pihak (Assaf dan Al-Hejji 2006). Haseeb et al. (2011) juga menjelaskan bahwa keterlambatan dalam pengerjaan proyek konstruksi merujuk pada meningkatnya biaya yang terjadi karena waktu pengerjaan menjadi lebih lama, peningkatan biaya tenaga kerja serta peningkatan biaya bahan bangunan.
Dalam pembangunan Apartemen sering kali banyak faktor yang memengaruhi penyelesaian pembangunan. Pada pembangunan apartemen di Surabaya, di mana banyak pembangunan proyek yang ditargetkan selesai dengan masa pembangunan, akan tetapi proyek tersebut tidak dapat selesai sesuai target dan mengalami kemoloran waktu pembangunan. Banyak sekali peristiwa yang terjadi di lapangan yang menghambat berjalannya pembangunan proyek apartemen di Surabaya.

Dengan adanya berbagai peristiwa penghambat pembangunan proyek yang mengakibatkan keterlambatan ini, maka perlu dilakukan evaluasi dan analisis mendalam yang berdasarkan analisis dan ilmiah terkait keterlambatan proyek pada pembangunan apartemen taman 
melati surabaya. Tujuan dari penelitian ini adalah menganalisis besar probabilitas dan peristiwa penyebab keterlambatan pembangunan proyek apartemen di Surabaya, dengan cara mengidentifikasi peristiwa penyebab menggunakan metode Fault Tree Analysis (FTA).

\section{TINJAUAN PUSTAKA}

Menurut Popescu dan Charoengam (1995), apabila dilihat berdasarkan tanggung jawabnya, keterlambatan dapat diklasifikasikan menjadi excusable delay, non-excusable delay, dan concurrent delay.

1. Keterlambatan yang tidak dapat dimaafkan (non-excusable delays). Non-excusable delays adalah keterlambatan yang diakibatkan oleh tindakan, kelalaian, atau kesalahan kontraktor.

2. Keterlambatan yang dapat dimaafkan (excusable delays). Excusable delays adalah keterlambatan yang disebabkan oleh kejadiankejadian di luar kendali baik pemilik maupun kontraktor. Pada kejadian ini, kontraktor mendapatkan kompensasi berupa perpanjangan waktu saja.

3. Keterlambatan yang layak mendapat ganti rugi (compensable delays). Compensable delays adalah keterlambatan yang diakibatkan tindakan, kelalaian atau kesalahan pemilik. Pada kejadian ini, kontraktor biasanya mendapatkan kompensasi berupa perpanjangan waktu dan tambahan biaya operasional yang perlu selama keterlambatan pelaksanaan tersebut.

\section{Penyebab Keterlambatan Konstruksi}

Menurut Barie (1984), keterlambatan disebabkan oleh pihak-pihak berbeda seperti berikut.
1. Pemilik atau wakilnya (delay caused by owner).

Bila pemilik atau wakilnya menyebabkan suatu keterlambatan, misalkan karena terlambat pemberian gambar kerja atau keterlambatan dalam memberikan persetujuan terhadap gambar, maka umumnya kontraktor akan diperkenankan untuk mendapatkan tuntutan yang sah untuk mendapatkan kompensasi ekstranya.

2. Keterlambatan yang disebabkan oleh kontraktor (contractor caused delay).

Keterlambatan semacam ini umumnya akan berakibat tidak diberikannya perpanjangan waktu dan tidak ada pemberian suatu kompensasi tambahan. Sesungguhnya pada situasi yang ekstrem maka hal-hal ini akan menyebabkan terputusnya ikatan kontrak.

3. Keterlambatan oleh pihak ketiga yang diperkenankan (excusable tried party delay.

Sering terjadi keterlambatan yang disebabkan oleh kekuatan yang berbeda di luar jangkauan pengendalian pihak pemilik atau kontraktor. Contohnya yang tidak dipersoalkan lagi di antaranya adalah kebakaran, banjir, gempa bumi dan hal yang lain disebut sebagai "tindakan Tuhan Yang Maha Kuasa”. Hal-hal lainnya yang sering kali menjadi masalah perselisihan meliputi pemogokan, embargo untuk pengangkutan, kecelakaan dan keterlambatan dalam menyerahkan yang bisa dimengerti. Termasuk pula yang tidak dimasukkan dalam kondisi yang telah ada pada saat penawaran dilakukan dan keadaan cuaca buruk.

\section{Fault Tree Analysis (FTA)}

Menurut Rosyid (2007), fault tree analysis adalah sebuah metode untuk mengidentifikasi semua sebab yang mungkin (kegagalan kompo- 
nen atau kejadian kegagalan lainnya yang terjadi sendiri atau bersama-sama) menyebabkan kegagalan sistem dan memberi pijakan perhitungan peluang kejadian kegagalan tersebut. FTA dapat dipakai untuk kasus dengan kombinasi kegagalan komponen, sehingga FTA cocok dipakai untuk sistem dengan redundansi.

Menurut (Kocecioglu, 1991 Analisis fault tree memiliki nilai penting dalam penyelesaian sebagai berikut.

1. Menganalisis kegagalan sistem.

2. Mencari aspek-aspek dari sistem yang terlibat dalam kegagalan utama.

3. Membantu pihak manajemen mengetahui perubahan dalam sistem.

4. Membantu mengalokasikan penganalisis untuk berkonsentrasi pada bagian kegagalan dalam sistem.

5. Membantu memberikan pilihan kualitatif, yang sama baiknya dengan kuantitatif, pada analisis sistem keandalan.

6. Membantu penganalisis menggunakan pengetahuannya untuk masuk dalam perilaku sistem.

Untuk menentukan minimal cut set yang digunakan untuk memberikan jawaban terhadap masalah FTA dengan menggunakan MOCUS (method obtain cut set). MOCUS (method for obtaining cut set) yaitu merupakan sebuah algoritma yang dipakai untuk mendapatkan minimal cut set. Menurut Clemens (2002) cut set adalah kombinasi pembentuk pohon kesalahan yang mana bila semua terjadi akan menyebabkan peristiwa puncak terjadi. Cut set digunakan untuk mengevaluasi diagram pohon kesalahan dan diperoleh dengan menggambarkan garis melalui blok dalam sistem untuk menunjukkan jumlah minimum blok gagal yang menyebabkan seluruh system gagal.
Namun bukan kombinasi peristiwa terkecil yang menyebabkan peristiwa puncak. Untuk mengetahuinya diperlukan minimal cut set. Minimal cut set ini adalah kombinasi peristiwa yang paling kecil yang membawa peristiwa yang tidak diinginkan (Billinton et al., 1992). Jika satu dari peristiwa-peristiwa dalam minimal cut set tidak terjadi, maka peristiwa puncak atau peristiwa yang tidak/diinginkan tidak akan terjadi. Dengan kata lain minimal cut set merupakan akar penyebab yang paling terkecil yang berpotensi menyebabkan kecacatan (peristiwa puncak).

Evaluasi kuantitatif fault tree yang dilakukan dengan menggunakan pendekatan perhitungan langsung (direct numerical approach) yang bersifat bottom-up approach. Pendekatan numerik ini berawal dari level hierarki yang paling rendah dan mengombinasikan semua probabilitas dari event yang ada pada level ini dengan menggunakan logic gate yang tepat di mana event-event ini dikaitkan. Kombinasi probabilitas ini akan memberikan nilai probabilitas dari intermediate event pada level hierarki di atasnya sampai top event dicapai.

Logic Gate pada fault tree analysis terdapat Gerbang OR dan AND. Di mana gerbang OR adalah gerbang yang menggambarkan gabungan dari kejadian-kejadian. Gerbang OR ekuivalen pada simbol “+”. Untuk n kejadian-kejadian masukan yang digambarkan pada gerbang OR ekuivalen dengan rumus $\mathrm{T}=\mathrm{C}_{1}+\mathrm{C}_{2}+. .+\mathrm{C}_{\mathrm{n}}$ untuk $\mathrm{T}$ adalah kejadian output (Probabilitas) dan $\mathrm{C}_{1}, \mathrm{C} 2, \ldots, \mathrm{C}_{\mathrm{n}}$ merupakan kejadian-kejadian masukan (Vesely dkk.2009). Sedangkan gerbang AND adalah gerbang yang menggambarkan irisan dari kejadian-kejadian. Gerbang AND ekuivalen dengan simbol “.” Untuk n kejadian-kejadian masukan pada gerbang AND ekuivalen dengan rumus $\mathrm{T}=\mathrm{C}_{1} \mathrm{xC}_{2} \mathrm{x} \cdot \mathrm{xC}_{\mathrm{n}}$ untuk $\mathrm{T}$ merupakan kejadian output (Probabilitas) dan $\mathrm{C}_{1}, \mathrm{C}_{2}, \ldots, \mathrm{C}_{\mathrm{n}}$ merupakan kejadian-kejadian masukan. 
Pada fault tree "0" diartikan sebagai kejadian gagal yang tidak terjadi dan " 1 " diartikan sebagai kejadian gagal yang terjadi. Dan penilaian probabilitas pad setiap basic event berdasarkan dari kriteria rating probabilitas yang dimiliki oleh (Heldman, 2005) seperti pada Tabel 1 berikut.

Tabel 1 Kriteria Rating Probabilitas

\begin{tabular}{|l|l|l|}
\hline Skor & \multicolumn{1}{|c|}{ Deskripsi } & \multicolumn{1}{c|}{ Definisi } \\
\hline 0,8 & Very critical & Selalu terjadi \\
\hline 0,6 & Critical & Sering terjadi \\
\hline 0,4 & Significant & Kadang-kadang terjadi \\
\hline 0,2 & Negligible & Kemungkinan kecil dapat terjadi \\
\hline 0,05 & Very negligible & Tidak pernah terjadi \\
\hline
\end{tabular}

Sumber: Heldman,2005

\section{METODE PENELITIAN}

Metode yang digunakan dalam survei ini menggunakan kuesioner dan wawancara terhadap para ahli/expert yang terkait dalam suatu proyek. Survei dilakukan kepada pemilik, manajemen konstruksi/konsultan pengawas, serta Kontraktor yang berada objek penelitian yaitu pada proyek pembangunan apartemen di Surabaya. Penetapan sampelnya menggunakan purposive sampling/judgment sampling yang merupakan non-probability sampling, sampel pada penelitian ini ditetapkan oleh peneliti dengan pertimbangan bahwa sampel tersebut dapat memberikan informasi yang akurat. Dalam mengumpulkan data penelitian maka perlu dilakukan dua pendekatan yaitu studi literatur dan studi langsung ke lapangan.

Data yang telah diperoleh kemudian di identifikasi dan di terjemahkan agar dapat diolah, untuk pengelolaan data kuesioner yang bersifat skala ordinal karena angka yang tercipta bersifat relatif subjektif maka untuk analisis data akan dilakukan analisis modus karena data yang diolah adalah data frekuensi maka modus sangat tepat digunakan untuk analisis data kuesioner pada penelitian ini. Penelitian ini difokuskan pada identifikasi peristiwa penyebab keterlambatan pada proses pembangunan proyek apartemen dengan metode fault tree analysis. Berikut merupakan langkah-langkah dalam penerapan FTA (Fault Tree Analysis) ini adalah sebagai berikut.

1. Mengidentifikasi masalah yang akan dianalisis (problem definition).

Penentuan masalah digunakan untuk mencari top event (peristiwa puncak), situasi atau keadaan penuh risiko yang teridentifikasi secara spesifik yang didapatkan potensi kawasan tersebut. Adapun syaratnya adalah sebagai berikut.

a. Pada FTA masalah adalah particular accidents atau main system failure yang digambarkan sebagai top event.

b. Top event jangan terlalu umum.

c. Top event jangan terlalu sempit.

d. Top event harus spesifik untuk masalah yang akan dianalisis, sebisa mungkin mengandung $3 \mathrm{~W}$, yaitu what, where, dan when.

2. Membuat gambar konstruksi fault tree. Penggambaran FTA dimaksudkan untuk mengetahui hubungan yang logis antara basic event dan top event yang telah ditentukan sebelumnya. Cara pembuatan FTA dimulai dari top event, kemudian ke event berikutnya sampai akhirnya ke basic event. Langkahlangkah pembuatan FTA (Gambar 3.2.) adalah sebagai berikut.

a. Menetapkan kejadian puncak (top event) yang telah ditentukan sebelumnya.

b. Menentukan intermediate event tingkat pertama terhadap kejadian puncak.

c. Menentukan hubungan intermediate event tingkat pertama terhadap kejadian puncak. 
d. Menentukan hubungan intermediate event tingkat pertama ke top event dengan menggunakan gerbang logika (logic gate).

e. Menentukan hubungan intermediate event tingkat kedua ke intermediate event tingkat pertama dengan menggunakan gerbang logika.

f. Melanjutkannya sampai ke basic event.

3. Setelah melakukan proses penyusunan diagram pohon kegagalan (fault tree analysis) dari faktor-faktor penyebab keterlambatan proyek, kemudian menentukan perhitungan kombinasi minimal cut set. Di dalam melakukan perhitungan minimal cut set menggunakan Notasi operator dalam logic gate, $O R$ Gate gerbang yang menggambarkan gabungan dari kejadian-kejadian merupakan penjumlahan probabilitas dan AND gate yang menggambarkan irisan dari kejadian-kejadian merupakan perkalian probabilitas menurut hukum probabilitas. Data probabilitas yang telah diberikan oleh responden ke dalam masingmasing basic event, kemudian dikalkulasi pada seluruh FTA. Adapun hasil perhitungan probabilitas dan konsekuensi dari kombinasi minimal cut set-nya adalah sebagai berikut.

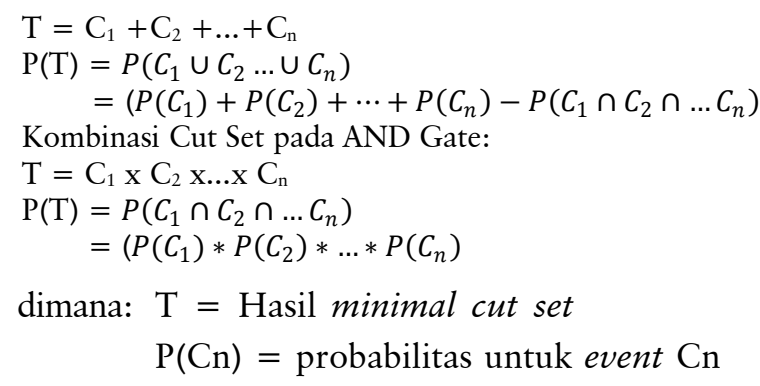

\section{HASIL DAN PEMBAHASAN}

\section{Identifikasi Peristiwa Penyebab Keterlambatan}

Di sini akan dijelaskan secara menyeluruh mengenai penyebab gagalnya keterlambatan pembangunan apartemen mulai dari peristiwa penyebab keterlambatan yang disebabkan oleh owner, kontraktor, manajemen konstruksi hingga disebabkan oleh faktor kondisi lingkungan terhadap proyek pembangunan apartemen taman melati surabaya. Semua proses tersebut akan dijabarkan dalam bentuk akar diagram pohon kesalahan FTA sehingga nantinya dapat diketahui penyebab dasar permasalahannya dan probabilitas masing-masing akar permasalahan tersebut.

Keterlambatan proyek pembangunan apartemen terbagi menjadi 4 peristiwa kejadian utama yaitu terlambatnya pengambilan tindakan oleh owner, kurangnya pengawasan yang dilakukan oleh manajemen konstruksi, pelaksanaan pekerjaan oleh kontraktor tidak berjalan lancar, dan terhambatnya pekerjaan oleh kondisi lingkungan dan sekitarnya (Gambar 1). Peristiwa-peristiwa

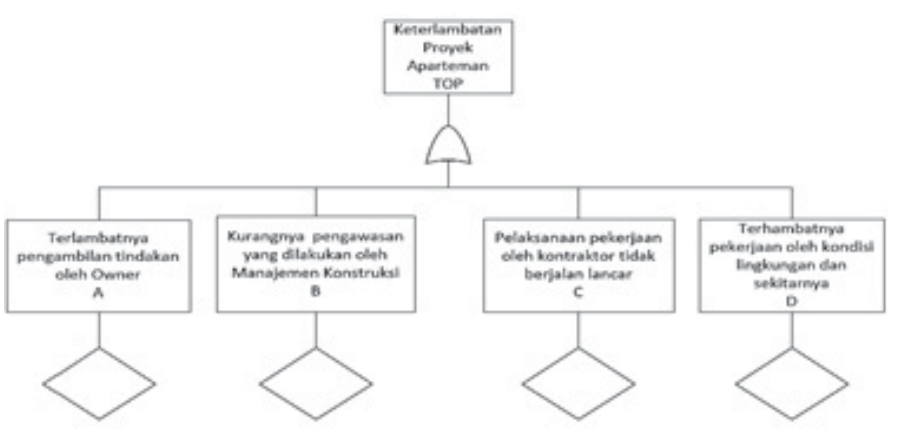

Gambar 1 FTA Top Event Keterlambatan Proyek Apartemen

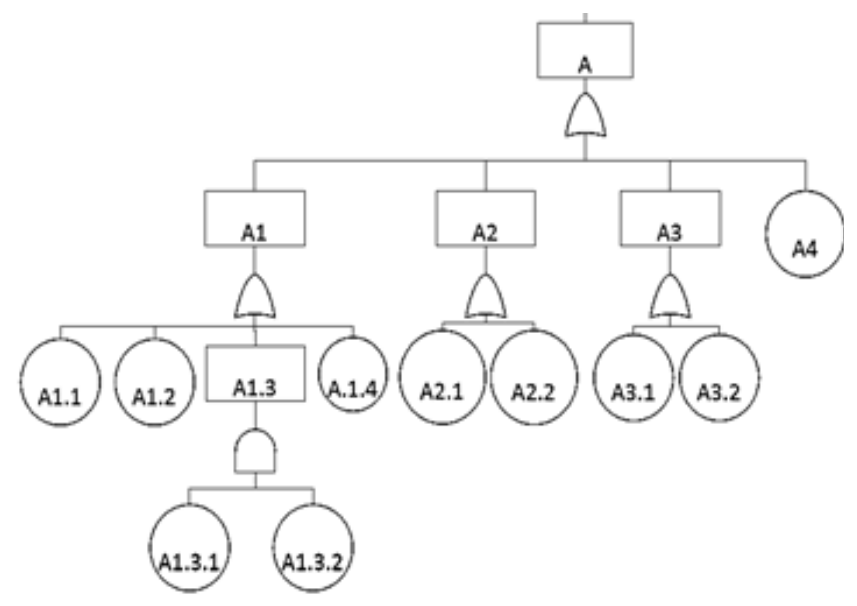

Gambar 2 FTA Terlambatnya Pengambilan Tindakan oleh Owner 
tersebut didapat berdasarkan studi literatur dan wawancara kuesioner kepada expert judgment sesuai kriteria responden yang ada pada proyek.

Setelah menentukan intermediate event utama kemudian mencari basic event/peristiwa penyebab utama dari keterlambatan Pada Gambar 2 merupakan diagram FTA terlambatnya pengambilan tindakan oleh owner.

Dari Gambar 2 didapat perhitungan kombinasi minimal cut set dengan persamaan sebagai berikut:

$$
\begin{aligned}
\mathrm{A}= & \mathrm{A} 1+\mathrm{A} 2+\mathrm{A} 3+\mathrm{A} 4 \\
= & (\mathrm{A} 1.1+\mathrm{A} 1.2+\mathrm{A} 1.3+\mathrm{A} 1.4)+(\mathrm{A} 2.1+\mathrm{A} 2.2)+ \\
& (\mathrm{A} 3.1+\mathrm{A} 3.2)+\mathrm{A} 4 \\
= & (\mathrm{A} 1.1+\mathrm{A} 1.2+(\mathrm{A} 1.3 .1 * \mathrm{~A} 1.3 .2)+\mathrm{A} 1.4)+(\mathrm{A} 2.1+ \\
& \mathrm{A} 2.2)+(\mathrm{A} 3.1+\mathrm{A} 3.2)+\mathrm{A} 4
\end{aligned}
$$

Berdasarkan dari persamaan di atas, kemudian dilakukan perhitungan kombinasi minimal cut set berdasarkan nilai probabilitas pada Tabel 2. Hasil probabilitas kombinasi minimal cut set pada peristiwa terlambatnya pengambilan tindakan oleh owner adalah 0,6878.

Tabel 2 Minimal Cut Set Peristiwa Terlambatnya Pengambilan Tindakan oleh Owner

\begin{tabular}{|l|l|c|}
\hline $\begin{array}{l}\text { Kode } \\
\text { Basic } \\
\text { Event }\end{array}$ & \multicolumn{1}{|c|}{ Basic Event } & Probabilitas \\
\hline A1.1 & $\begin{array}{l}\text { Terlambatnya merevisi dan menyetujui } \\
\text { perubahan desain }\end{array}$ & 0,2 \\
\hline A1.2 & $\begin{array}{l}\text { Terlambatnya menyetujui approval } \\
\text { material }\end{array}$ & 0,4 \\
\hline A1.3.1 & $\begin{array}{l}\text { Penambahan atau pengurangan } \\
\text { pekerjaan }\end{array}$ & 0,2 \\
\hline A1.3.2 & Penggantian pekerjaan & 0,4 \\
\hline A1.4 & $\begin{array}{l}\text { Penerapan standard yang terlalu tinggi } \\
\text { pada setiap pekerjaan }\end{array}$ & 0,4 \\
\hline A2.1 & $\begin{array}{l}\text { Terlambatnya angsuran pembayaran } \\
\text { kontraktor }\end{array}$ & 0,4 \\
\hline A2.2 & $\begin{array}{l}\text { Kesalahan dalam pengelolaan } \\
\text { keuangan proyek }\end{array}$ & $\begin{array}{l}\text { Kurang koordinasi dan komunikasi } \\
\text { oleh owner kepada manajemen } \\
\text { konstruksi dan Kontraktor }\end{array}$ \\
\hline A3.1 & $\begin{array}{l}\text { Terlambat pemilik memberikan } \\
\text { instruksi }\end{array}$ & $\begin{array}{l}\text { Pekerjaan yang terhambat akibat } \\
\text { kurangnya kesiapan lahan }\end{array}$ \\
\hline A3 & 0,2 \\
\hline A4 & $\begin{array}{l}\text { Mint Set } \\
0,6878\end{array}$ \\
\hline
\end{tabular}

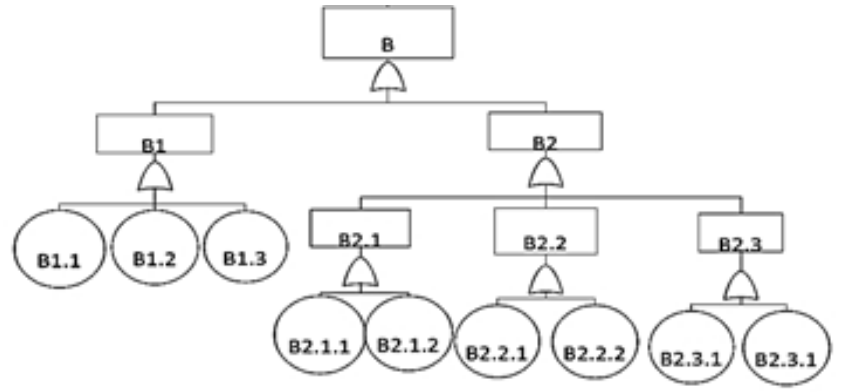

Gambar 3 FTA Kurangnya Pengawasan yang Dilakukan oleh Manajemen Konstruksi

Dari Gambar 3 didapat perhitungan kombinasi minimal cut set dengan persamaan sebagai berikut:

$$
\begin{aligned}
\mathrm{B}= & \mathrm{B} 1+\mathrm{B} 2 \\
= & (\mathrm{B} 1.1+\mathrm{B} 1.2+\mathrm{B} 1.3)+(\mathrm{B} 2.1+\mathrm{B} 2.2+\mathrm{B} 2.3) \\
= & (\mathrm{B} 1.1+\mathrm{B} 1.2+\mathrm{B} 1.3)+((\mathrm{B} 2.1 .1+\mathrm{B} 2.1 .2)+ \\
& (\mathrm{B} 2.2 .1+\mathrm{B} 2.2 .2)+(\mathrm{B} 2.3 .1+\mathrm{B} 2.3 .2)
\end{aligned}
$$

Berdasarkan dari persamaan di atas, kemu-

\begin{tabular}{|c|c|c|}
\hline $\begin{array}{l}\text { Kode } \\
\text { Basic } \\
\text { Event }\end{array}$ & Basic Event & Probabilitas \\
\hline B1.1 & $\begin{array}{l}\text { Terlambatnya menyetujui perubahan } \\
\text { besar dari desain }\end{array}$ & 0,2 \\
\hline B1.2 & $\begin{array}{l}\text { terhambatnya pekerjaan karena } \\
\text { kurangnya pengawalan desain }\end{array}$ & 0,2 \\
\hline B1.3 & terlambatnya menyetujui shop drawing & 0,2 \\
\hline B2.1.1 & $\begin{array}{l}\text { Seringnya penagihan persetujuan shop } \\
\text { drawing dan spektek oleh kontraktor }\end{array}$ & 0,4 \\
\hline B2.1.2 & $\begin{array}{l}\text { Terlambatnya penanganan administrasi } \\
\text { secara prosedural oleh staff manajemen } \\
\text { konstruksi }\end{array}$ & 0,4 \\
\hline B2.2.1 & $\begin{array}{l}\text { Hasil meeting/koordinasi tidak } \\
\text { dilaksanakan atau salah melaksanakan }\end{array}$ & 0,4 \\
\hline B2.2.2 & $\begin{array}{l}\text { Seringnya miss-komunikasi manajemen } \\
\text { konstruksi kepada owner dan } \\
\text { kontraktor }\end{array}$ & 0,2 \\
\hline B2.3.1 & $\begin{array}{l}\text { Terlambatnya peninjauan pekerjaan } \\
\text { oleh manajemen konstruksi }\end{array}$ & 0,2 \\
\hline B2.3.1 & $\begin{array}{l}\text { Hasil evaluasi/checklist pekerjaan } \\
\text { belum bisa dikerjakan }\end{array}$ & 0,6 \\
\hline & Minimal Cut Set & 0,8558 \\
\hline
\end{tabular}
dian dilakukan perhitungan kombinasi minimal cut set berdasarkan nilai probabilitas pada Tabel 3. Hasil probabilitas minimal cut set pada peristiwa terlambatnya pengambilan tindakan oleh owner adalah 0,8558 .

Tabel 3 Minimal Cut Set Peristiwa Kurangnya Pengawasan yang Dilakukan oleh Manajemen Konstruksi 
Dari Gambar 3 merupakan diagram FTA pelaksanaan pekerjaan oleh kontraktor tidak berjalan lancar. Pada Gambar 4, Gambar 5, dan Gambar 6 merupakan pencarian basic event pada peristiwa penyebab oleh kontraktor.

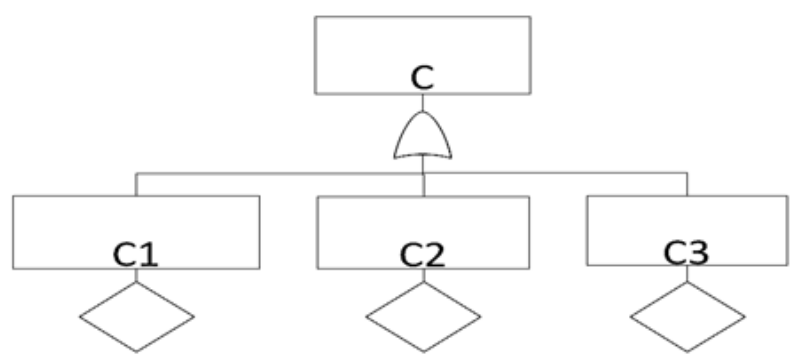

Gambar 4 FTA Pelaksanaan Pekerjaan oleh Kontraktor Tidak Berjalan Lancar

Di bawah ini merupakan tabel probabilitas dan hasil kombinasi minimal cut set dari peristiwa pelaksanaan pekerjaan oleh kontraktor tidak berjalan lancar.

Tabel 4 Minimal Cut Set Peristiwa Pelaksanaan Pekerjaan oleh Kontraktor Tidak Berjalan Lancar

\begin{tabular}{|l|l|c|}
\hline $\begin{array}{c}\text { Kode } \\
\text { Basic } \\
\text { Event }\end{array}$ & \multicolumn{1}{|c|}{ Basic Event } & Probabilitas \\
\hline C1.1.1 & $\begin{array}{l}\text { Tidak lengkapnya identifikasi } \\
\text { permasalahan pada setiap pekerjaan }\end{array}$ & 0,2 \\
\hline C1.1.2 & $\begin{array}{l}\text { Rencana kerja yang tidak tersusun } \\
\text { dengan baik }\end{array}$ & 0,2 \\
\hline C1.1.3 & $\begin{array}{l}\text { Penentuan durasi waktu yang tidak } \\
\text { sesuai }\end{array}$ & 0,2 \\
\hline C1.1.4 & $\begin{array}{l}\text { Metode pelaksanaan pekerjaan yang } \\
\text { tidak tepat }\end{array}$ & 0,6 \\
\hline C1.1.5 & $\begin{array}{l}\text { Action plan mingguan yang tidak } \\
\text { berjalan }\end{array}$ & 0,4 \\
\hline C1.2.1.1 & $\begin{array}{l}\text { Kontrol target pekerjaan tidak sesuai } \\
\text { dari rencana }\end{array}$ & 0,2 \\
\hline C1.2.1.2 & $\begin{array}{l}\text { kurangnya kontrol terhadap kualitas } \\
\text { pekerjaan }\end{array}$ & 0,2 \\
\hline C1.2.1.3 & $\begin{array}{l}\text { Kurangnya kontrol terhadap desain dan } \\
\text { perubahannya }\end{array}$ & 0,2 \\
\hline C1.2.1.4 & kurangnya kontrol perhitungan material & 0,2 \\
\hline C1.2.1.5 & $\begin{array}{l}\text { Buruknya pengarahan kepada tenaga } \\
\text { kerja }\end{array}$ & 0,2 \\
\hline C1.2.2 & $\begin{array}{l}\text { Perbedaan jadwal main kontraktor } \\
\text { dengan vendor lain dalam penyelesaian } \\
\text { pekerjaan }\end{array}$ & 0,4 \\
\hline C1.2.3 & Monitoring dan evaluasi tidak berjalan & 0,2 \\
\hline C2.1.1 & $\begin{array}{l}\text { kurang memadai dan jelasnya penjelasan } \\
\text { gambar detail pada desain }\end{array}$ & 0,2 \\
\hline C2.1.2 & $\begin{array}{l}\text { Timbulnya perbedaan gambar dalam } \\
\text { dokumen desain }\end{array}$ & 0,2 \\
\hline
\end{tabular}

\begin{tabular}{|c|c|c|}
\hline $\mathrm{C} 2.1 .3$ & $\begin{array}{l}\text { Terlambatnya penyampaian perubahan } \\
\text { desain terbaru ke lapangan }\end{array}$ & $\overline{0,4}$ \\
\hline $\mathrm{C} 2.2 .1 .1$ & $\begin{array}{l}\text { Terlambatnya pekerja memasuki lahan } \\
\text { kerjanya }\end{array}$ & 0,2 \\
\hline $\mathrm{C} 2.2 .1 .2$ & $\begin{array}{l}\text { Banyaknya pekerja usia kurang } \\
\text { produktif dalam proyek }\end{array}$ & 0,05 \\
\hline C2.2.1.3 & Terjadinya pekerjaan rework dan repair & 0,2 \\
\hline $\mathrm{C} 2.2 .2$ & $\begin{array}{l}\text { Ketersediaan tenaga kerja yang kurang } \\
\text { memadai terhadap lahan }\end{array}$ & 0,2 \\
\hline $\mathrm{C} 2.2 .3 .1$ & $\begin{array}{l}\text { Terlambatnya pembayaran kepada } \\
\text { mandor }\end{array}$ & 0,2 \\
\hline $\mathrm{C} 2.2 .3 .2$ & $\begin{array}{l}\text { Pekerja menginginkan kenaikan upah } \\
\text { kerja }\end{array}$ & 0,2 \\
\hline C2.3.1.1 & Terlambatnya kedatangan material & 0,4 \\
\hline $\mathrm{C} 2.3 .1 .2$ & $\begin{array}{l}\text { Tidak adanya supplier terhadap spek } \\
\text { material }\end{array}$ & 0,4 \\
\hline C2.3.1.3 & jumlah material yang dikirim tidak tepat & 0,2 \\
\hline $\mathrm{C} 2.3 .2$ & $\begin{array}{l}\text { Adanya perubahan spesifikasi dan tipe } \\
\text { material }\end{array}$ & 0,2 \\
\hline $\mathrm{C} 2.3 .3$ & $\begin{array}{l}\text { banyaknya kualitas material yg tidak } \\
\text { sesuai standar }\end{array}$ & 0,2 \\
\hline $\mathrm{C} 2.4 .1 .1$ & Terlambatnya pengadaan alat kerja & 0,2 \\
\hline $\mathrm{C} 2.4 .1 .2$ & Bergantiannya pemakaian alat kerja & 0,2 \\
\hline $\mathrm{C} 2.4 .1 .3$ & $\begin{array}{l}\text { Mudah rusaknya peralatan yang } \\
\text { digunakan }\end{array}$ & 0,2 \\
\hline $\mathrm{C} 2.4 .2 .1$ & $\begin{array}{l}\text { Penggunaan alat pada pekerja yang } \\
\text { bukan ahlinya }\end{array}$ & 0,05 \\
\hline $\mathrm{C} 2.4 .2 .2$ & $\begin{array}{l}\text { Kurang produktif dan efisien dalam } \\
\text { penggunaan alat }\end{array}$ & 0,4 \\
\hline $\mathrm{C} 2.5 .1 .1$ & $\begin{array}{l}\text { Banyaknya keluhan mandor atau subkon } \\
\text { terhadap tempat penyimpanan material }\end{array}$ & 0,2 \\
\hline $\mathrm{C} 2.5 .1 .2$ & $\begin{array}{l}\text { Banyaknya keluhan terhadap ruang kerja } \\
\text { dan kesiapan lahan di lapangan }\end{array}$ & 0,4 \\
\hline C2.5.2.1 & $\begin{array}{l}\text { Seringnya komplain dan demo oleh } \\
\text { warga sekitar proyek }\end{array}$ & 0,2 \\
\hline $\mathrm{C} 2.5 .2 .2$ & $\begin{array}{l}\text { Banyaknya keluhan vendor material } \\
\text { terhadap akses keluar masuk material }\end{array}$ & 0,4 \\
\hline C3.1.1 & $\begin{array}{l}\text { Kurangnya koordinasi antar staf di } \\
\text { lapangan }\end{array}$ & 0,2 \\
\hline C3.1.2 & $\begin{array}{l}\text { Kurangnya komunikasi kontraktor } \\
\text { dengan konsultan dan owner }\end{array}$ & 0,2 \\
\hline C3.2 & $\begin{array}{l}\text { Kesalahan pengarahan staff teknik } \\
\text { dalam pekerjaan }\end{array}$ & 0,05 \\
\hline $\mathrm{C} 3.3$ & $\begin{array}{l}\text { seringnya perubahan job description } \\
\text { pada pelaksana di lapangan }\end{array}$ & 0,2 \\
\hline \multicolumn{2}{|c|}{ Minimal Cut Set } & 0,9997 \\
\hline
\end{tabular}

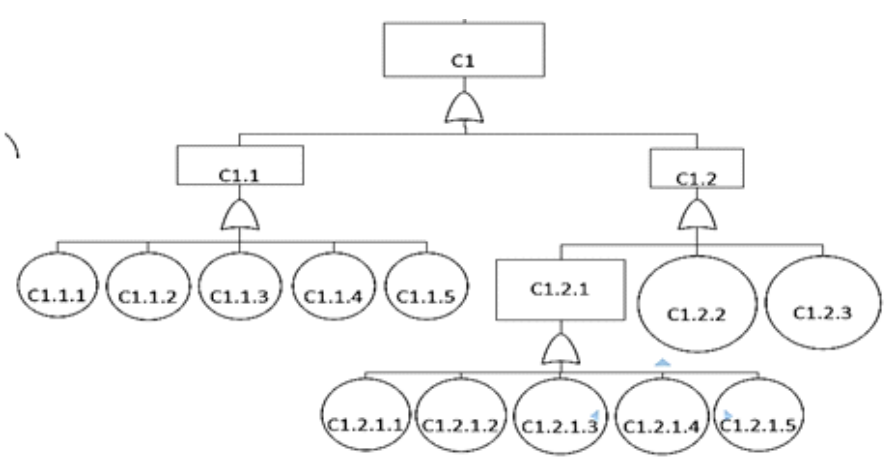

Gambar 5 FTA Kurang Matangnya Perencanaan dan Pengontrolan oleh Kontraktor 
Berdasarkan Gambar 5 didapat perhitungan kombinasi minimal cut set dengan persamaan sebagai berikut:

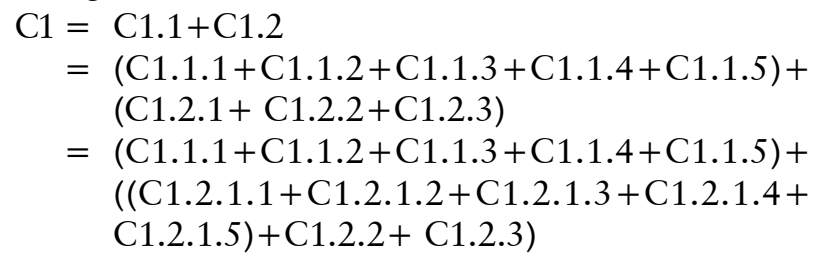

Berdasarkan dari persamaan di atas, kemudian dilakukan perhitungan kombinasi minimal cut set berdasarkan nilai probabilitas pada Tabel 4. Hasil probabilitas kombinasi minimal cut set pada peristiwa kurang matangnya perencanaan dan pengontrolan oleh kontraktor adalah 0,9850 .

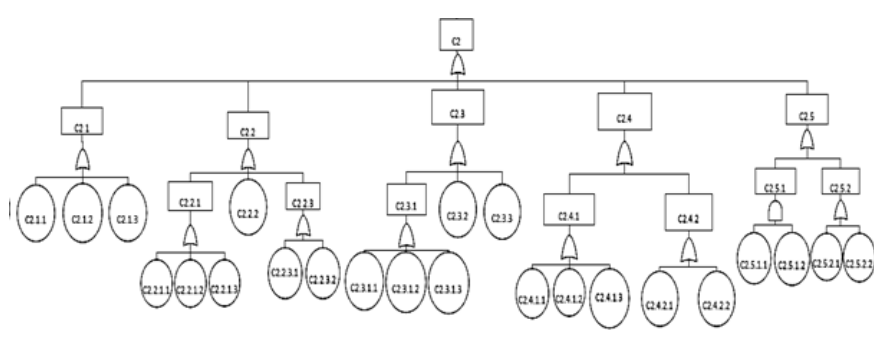

Gambar 6 FTA Sistem Produksi Tidak Berjalan Lancar

Dari Gambar 6 peristiwa sistem produksi yang tidak berjalan lancar bisa didapat perhitungan kombinasi minimal cut set dengan persamaan sebagai berikut:

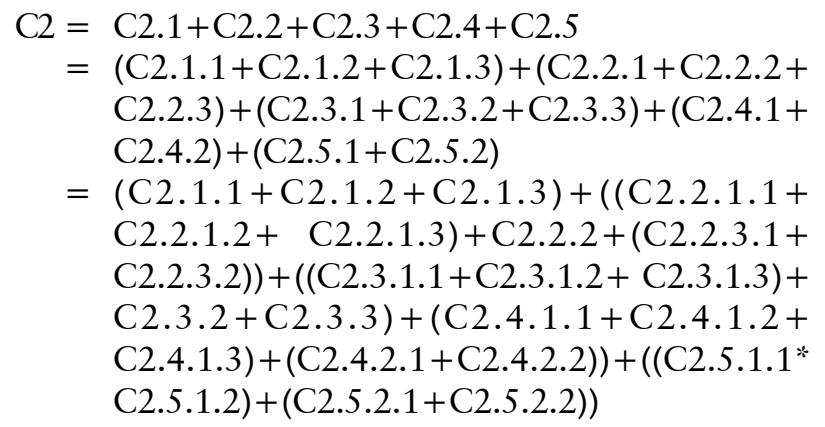

$=(\mathrm{C} 2.1 .1+\mathrm{C} 2.1 .2+\mathrm{C} 2.1 .3)+(\mathrm{C} 2.2 .1+\mathrm{C} 2.2 .2+$ $\mathrm{C} 2.2 .3)+(\mathrm{C} 2.3 .1+\mathrm{C} 2.3 .2+\mathrm{C} 2.3 .3)+(\mathrm{C} 2.4 .1+$ $\mathrm{C} 2.4 .2)+(\mathrm{C} 2.5 .1+\mathrm{C} 2.5 .2)$

$=(\mathrm{C} 2.1 .1+\mathrm{C} 2.1 .2+\mathrm{C} 2.1 .3)+((\mathrm{C} 2.2 .1 .1+$ $\mathrm{C} 2.2 .1 .2+\mathrm{C} 2.2 .1 .3)+\mathrm{C} 2.2 .2+(\mathrm{C} 2.2 .3 .1+$ $\mathrm{C} 2.2 .3 .2))+((\mathrm{C} 2 \cdot 3 \cdot 1.1+\mathrm{C} 2 \cdot 3 \cdot 1.2+\mathrm{C} 2.3 \cdot 1.3)+$ $\mathrm{C} 2.3 .2+\mathrm{C} 2.3 .3)+(\mathrm{C} 2.4 \cdot 1.1+\mathrm{C} 2.4 \cdot 1.2+$ $\mathrm{C} 2 \cdot 4 \cdot 1.3)+(\mathrm{C} 2 \cdot 4 \cdot 2 \cdot 1+\mathrm{C} 2 \cdot 4 \cdot 2.2))+\left(\left(\mathrm{C} 2 \cdot 5 \cdot 1.1^{*}\right.\right.$ $\mathrm{C} 2.5 .1 .2)+(\mathrm{C} 2.5 \cdot 2.1+\mathrm{C} 2.5 .2 .2))$

Berdasarkan dari persamaan di atas, kemudian dilakukan perhitungan kombinasi minimal cut set berdasarkan nilai probabilitas pada Tabel 4. Hasil probabilitas kombinasi minimal cut set pada peristiwa sistem produksi yang tidak berjalan lancar adalah 0,9595.

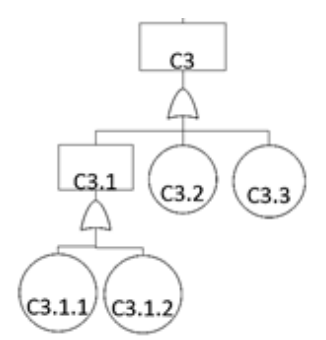

\section{Gambar 7 FTA Buruknya Sistem Manajemen Kontraktor}

Dari Gambar 7 peristiwa buruknya manajemen pada kontraktor bisa didapat perhitungan kombinasi minimal cut set dengan persamaan sebagai berikut:

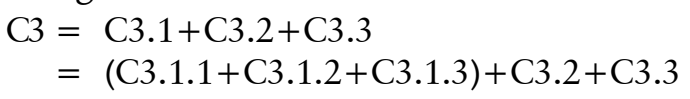

Berdasarkan dari persamaan di atas, kemudian dilakukan perhitungan kombinasi minimal cut set berdasarkan nilai probabilitas pada Tabel 4. Hasil probabilitas kombinasi minimal cut set pada peristiwa buruknya manajemen pada kontraktor adalah 0,5136.

Setelah dilakukan perhitungan kombinasi minimal cut set pada C1, C2, dan C3. Selanjutnya melakukan perhitungan kombinasi minimal cut set pada kode C (Peristiwa pelaksanaan pekerjaan kontraktor tidak berjalan baik) dengan persamaan $\mathrm{C}=\mathrm{C} 1+\mathrm{C} 2+\mathrm{C} 3$. Berdasarkan hasil perhitungan probabilitas kombinasi minimal cut set pada $\mathrm{C} 1=0,9850, \mathrm{C} 2=0,9595$, dan $\mathrm{C} 3=$ 0,5136. Maka diperoleh probabilitas kombinasi minimal cut set pada peristiwa pelaksanaan pekerjaan kontraktor tidak berjalan baik sebesar 0,9997 .

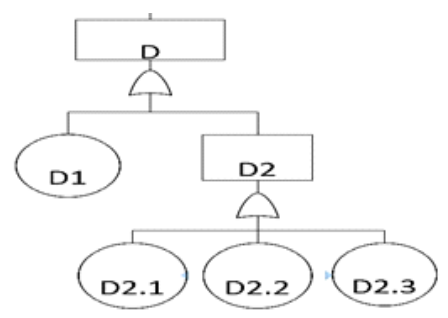

Gambar 8 FTA Terhambatnya Pekerjaan oleh Kondisi Lingkungan Sekitar 
Dari Gambar 8 didapat perhitungan kombinasi minimal cut set dengan persamaan sebagai berikut:

$$
\begin{aligned}
\mathrm{D} & =\mathrm{D} 1+\mathrm{D} 2 \\
& =\mathrm{D} 1+(\mathrm{D} 2.1+\mathrm{D} 2.2+\mathrm{D} 2.3)
\end{aligned}
$$

Berdasarkan dari persamaan di atas, kemudian dilakukan perhitungan kombinasi minimal cut set berdasarkan nilai probabilitas pada Tabel 5. Hasil probabilitas kombinasi minimal cut set pada peristiwa terlambatnya pengambilan tindakan oleh owner adalah 0,8272 .

Tabel 5 Minimal Cut Set Peristiwa Terhambatnya Pekerjaan oleh Kondisi Lingkungan dan Sekitarnya

\begin{tabular}{|l|l|c|}
\hline $\begin{array}{c}\text { Kode } \\
\text { Basic } \\
\text { Event }\end{array}$ & \multicolumn{1}{|c|}{ Basic Event } & Probabilitas \\
\hline D1 & $\begin{array}{l}\text { Intensitas cuaca atau tingginya } \\
\text { curah hujan/panas }\end{array}$ & 0,4 \\
\hline D2.1 & $\begin{array}{l}\text { Kesulitan sosialisasi dan negosiasi } \\
\text { amdal terhadap warga }\end{array}$ & 0,2 \\
\hline D2.2 & $\begin{array}{l}\text { Terganggunya warga karena } \\
\text { proyek terlalu berdekatan }\end{array}$ & 0,4 \\
\hline D2.3 & $\begin{array}{l}\text { Banyaknya kerusakan pada } \\
\text { bangunan warga sekitar }\end{array}$ & 0,4 \\
\hline \multicolumn{1}{|c|}{ Minimal Cut Set } & 0,8272 \\
\hline
\end{tabular}

Setelah diketahui masing-masing kombinasi minimal cut set dari intermediate event utama FTA. Untuk peristiwa "terlambatnya pengambilan tindakan oleh owner" probabilitasnya adalah 0,6878, kemudian untuk "Kurangnya pengawasan yang dilakukan oleh Manajemen Konstruksi” adalah 0,8558, untuk "pelaksanaan pekerjaan oleh kontraktor tidak berjalan lancar" yaitu 0,9997, dan untuk "terhambatnya pekerjaan oleh kondisi lingkungan dan sekitar" adalah 0,8272 . Jadi jumlah total probabilitas kombinasi minimal cut set untuk top event adalah:

$$
\begin{aligned}
\mathrm{T} & =\mathrm{C} 1+\mathrm{C} 2+\ldots+\mathrm{Cn} \\
T & =A+\mathrm{B}+\mathrm{C}-+\mathrm{D}- \\
& =0,6878+0,8558+0,9997+0,8272 \\
& =0,7342
\end{aligned}
$$

\section{KESIMPULAN}

\section{Kesimpulan}

Dari penelitian yang sudah dilakukan, metode fault tree analysis bertujuan untuk mencari peristiwa penyebab utama pada keterlambatan proyek apartemen di Surabaya. Berdasarkan analisis FTA didapat 62 variabel peristiwa penyebab utama. Dari 62 variable penyebab tersebut didapat peristiwa penyebab keterlambatan yang paling dominan pada owner adalah banyaknya penggantian pekerjaan, terlambatnya angsuran pembayaran ke kontraktor. Penyebab dari konsultan pengawas adalah hasil cek pekerjaan belum bisa di lanjutkan. Penyebab dari kontraktor metode pelaksanaan yang tidak tepat. Untuk penyebab dari kondisi lingkungan adalah terganggunya warga sekitar karena proyek terlalu berdekatan. Untuk hasil probabilitas keseluruhan peristiwa penyebab "Keterlambatan pembangunan proyek Apartemen di Surabaya berdasarkan analisis FTA adalah sebesar 0.7342 .

\section{DAFTAR PUSTAKA}

Assaf, S.A. dan Al-Hejji, S. 2006. "Causes of Delay in Large Construction Projects". International Journal of Project Management, 24(4), 349-57.

Barrie, D.S., Paulson Jr., dan Boyd C. 1984. Professional Construction Management. New York: McGraw-Hill, Inc.

Billinton, R., dan Allan R.N. 1992. Reliability Evaluation of Engineering System Concepts and Techniques. New York dan London: Plenum Press, Edisi 2.

Haseeb, M. Lu, X. dan Bibi, A. 2011. "Problems of Projects and Effects of Delays in the Construction Industry of Pakistan". Australian Journal of Business and Man- 
agement Research, Vol.1, No.5, [41-50]| September 2011.

Heldman, K. 2005. Project Manager's Spotlight on Risk Management. Alameda: Harbor Light Press.

Kocecioglu, D. 1991. Reliability Engineering Handbook, Volume 2. Englewood Cliffs: Prentice-Hall.
Popescu, C.M. dan Charoengam, C. 1995. Project Planning, Scheduling, and Control in Construction, p.188. Canada: John Willey \& Son.

Rosyid, D.M. 2007. Pengantar Rekayasa Keandalan. Surabaya: Airlangga University Press. Vesely, W.E. 1981. "Fault Tree Handbook". Washington, D.C.: U.S. Nuclear Regulatory Commission. 